\title{
Relationship of Silverleaf Whitefly Population Density to Severity of Irregular Ripening of Tomato
}

\author{
David J. Schuster \\ Gulf Coast Research \& Education Center, 5007 60th Street East, Bradenton, \\ FL 34203
}

Additional index words. Bemisia argentifolii, Lycopersicon esculentum, integrated pest
management, action threshold

Abstract. The silverleaf whitefly (Bemisia argentifolii Bellows \& Perring) is an important pest of tomatoes in Florida and elsewhere. Associated with populations of the whitefly is an irregular ripening disorder of fruit characterized by inhibited or incomplete ripening of longitudinal sections of fruit and by an increase in the amount of interior white tissue. Experiments were conducted during the spring and fall tomato production seasons of 1995 and 1996 to elucidate the relationship of nymphal and pupal density with severity of the disorder. Insecticides or insecticide combinations were applied at predetermined densities of whitefly nymphs and pupae and the subsequent severity of the disorder was rated separately for external and internal symptoms on red ripe fruit harvested weekly. Expression of irregular ripening symptoms, especially external symptoms, were correlated positively to the density of whitefly nymphs and pupae (number $10^{-1}$ terminal leaflets on the seventh to eighth leaf from the top of a main or lateral stem) increased. Expression of external symptoms tended to be better correlated with whitefly density when symptom severity was rated 1 and 3 weeks after estimating whitefly density for the spring and fall seasons, respectively. Expression of internal symptoms tended to be more consistently correlated with whitefly density when symptom severity was rated 2 and 3 weeks after estimating whitefly density for the spring and fall seasons, respectively.

The silverleaf whitefly (SLWF), formerly strain B of the sweetpotato whitefly $B$. tabaci (Gennadius), has been an important insect pest of tomatoes in Florida since 1988 (Schuster et al., 1996). Associated with infestations of the pest is an irregular ripening (IRR) disorder characterized by incomplete or inhibited ripening of longitudinal sections of fruit (Schuster et al., 1990). An increased amount of internal white tissue, which normally occurs to some extent in fruit from noninfested plants, is associated with the disorder. The disorder is not associated with any foliar symptoms and is not apparent on fruit until red ripening occurs. Eliminating whitefly infestations resulted in normal fruit subsequently being produced (Schuster et al., 1990). A relationship between nymphal densities of the SLWF and IRR was suggested but was not defined (Schuster et al., 1990). The purpose of the present investigation was to establish gradients in densities of SLWF nymphs and pupae and compare the relationship of density with subsequent symp-

\footnotetext{
Received for publication 19 Oct. 2000. Accepted for publication 28 Feb. 2001. Florida Agricultural Expt. Station Journal Series No. R-07840. I thank the Florida Tomato Committee for partial support of the research and Emily Vasquez, Kevin Hearne, Oswaldo Toribio, Emerson Alder, and Tim Davis for the many hours spent applying treatments, counting whiteflies, and evaluating fruit. The cost of publishing this paper was defrayed in part by the payment of page charges. Under postal regulations, this paper therefore must be hereby marked advertisement solely to indicate this fact.
}

tom expression of IRR. This information would be useful in developing action thresholds for integrated pest management programs.

\section{Materials and Methods}

Four experiments were conducted at the Gulf Coast Research \& Education Center, Bradenton, Fla., during the spring and fall tomato production seasons of 1995 and 1996. Plots were three 9-m-long rows with 20 plants/ row. Plots were separated by $6 \mathrm{~m}$ and were replicated four times in randomized complete blocks for each experiment and were exposed to naturally occurring populations of the SLWF. Sessile nymphs and pupae of the SLWF were counted weekly on the terminal leaflet of the seventh to eighth leaf from the tops of 10 plants from the middle row of each plot (Schuster, 1998). In Spring 1995, counts also were made on 20,15-mm disks (two each from each terminal leaflet). When predetermined densities of SLWF nymphs or pupae were reached or exceeded, insecticides or insecticide combinations were applied as foliar sprays. The densities selected were based upon preliminary research conducted previously in field cage studies (Schuster et al., 1990) and consisted of $\geq 40, \geq 60$, and $\geq 80$ nymphs or pupae/ 20 leaf disks for Spring 1995; and $\geq 5, \geq 10$, $\geq 20$, and $\geq 40$ nymphs or pupae/10 leaflets for Fall 1995 and Fall and Spring 1996. Insecticide treatments included the combination of fenpropathrin (Danitol ${ }^{\mathrm{TM}}$ 2.4EC; Valent USA Corp., Walnut Creek, Calif.) at $0.22 \mathrm{~kg} \cdot \mathrm{ha}^{-1}$ a.i. and methamidophos (Monitor ${ }^{\mathrm{TM}}$ 4EC,
Valent USA Corp., Walnut Creek, Calif.) at $0.84 \mathrm{~kg} \cdot \mathrm{ha}^{-1}$ a.i. in Spring 1995; imidacloprid Provado $^{\mathrm{TM}} 1.6 \mathrm{~F}$; Bayer Corp., Kansas City, Mo.) at $0.056 \mathrm{~kg} \cdot \mathrm{ha}^{-1}$ a.i. alone or the combination of lambda-cyhalothrin (Warrior ${ }^{\mathrm{TM}} 1 \mathrm{EC}$; Zeneca Ag Products, Wilmington, Del.) at $0.074 \mathrm{~kg} \cdot \mathrm{ha}^{-1}$ a.i. plus methamidophos at 0.84 $\mathrm{kg} \cdot \mathrm{ha}^{-1}$ a.i. in Fall 1995; the combination of fenpropathrin at $0.22 \mathrm{~kg} \cdot \mathrm{ha}^{-1}$ a.i. and methamidophos at $0.84 \mathrm{~kg} \cdot \mathrm{ha}^{-1}$ a.i. or the combination of CGA 215994 50WP (Novartis Crop Protection, Greensboro, N.C.) at 0.26 $\mathrm{kg} \cdot \mathrm{ha}^{-1}$ a.i. and fenoxycarb 25WP (Novartis Crop Protection) at $0.17 \mathrm{~kg} \cdot \mathrm{ha}^{-1}$ a.i. and silicon adjuvant (Silwet ${ }^{\mathrm{TM}}$ L-77; Helena Chemical Company, Memphis, Tenn.) at $0.05 \% \mathrm{v} / \mathrm{v}$ for Spring 1996; and the combination of fenpropathrin at $0.22 \mathrm{~kg} \cdot \mathrm{ha}^{-1}$ a.i. and methamidophos at $0.84 \mathrm{~kg} \cdot \mathrm{ha}^{-1}$ a.i. or the combination of pyriproxyfen $\left(\mathrm{Knack}^{\mathrm{TM}} 0.86 \mathrm{EC}\right.$; Valent USA Corp.) at $0.07 \mathrm{~kg} \cdot \mathrm{ha}^{-1}$ a.i. and endosulfan (Phaser ${ }^{\mathrm{TM}}$ 3EC; Aventis CropScience, Research Triangle Park, N.C.) at 1.12 $\mathrm{kg} \cdot \mathrm{ha}^{-1}$ a.i. for Fall 1996. All foliar sprays were applied with a self-propelled, high-clearance sprayer at $1340 \mathrm{Kpascals}$ and 561-1122 L $\cdot \mathrm{ha}^{-1}$, depending upon plant height. Control plots with noinsecticide applications were included in Spring 1995 experiment and whitefly-free checks were included in all experiments. To help ensure that no immature whiteflies were present on the whitefly-free check plots, they were treated with imidacloprid (Admire ${ }^{\mathrm{TM}}$; Bayer Corp.) at transplanting at $1.2 \mathrm{~L} \cdot \mathrm{ha}^{-1}$ and later by weekly applications of either fenpropathrin at $0.22 \mathrm{~kg} \cdot \mathrm{ha}^{-1}$ a.i. and methamidophos at $0.84 \mathrm{~kg} \cdot \mathrm{ha}^{-1}$ a.i. or lambdacyhalothrin at $0.03 \mathrm{~kg} \cdot \mathrm{ha}^{-1}$ a.i. and methamidophos at $0.84 \mathrm{~kg} \cdot \mathrm{ha}^{-1}$ a.i. Control plots, whitefly-free check plots and all thresholdtreated plots were replicated four times in randomized complete-block designs.

Red ripe fruits were harvested weekly and rated 1 to 4 for increasing severity of external symptoms of IRR: 1 for no symptoms, 2 for a distinct "star" on the blossom end with points radiating up the fruit, 3 for $\leq 30 \%$ of the fruit surface affected, and 4 for $>30 \%$ of the fruit surface affected. Each fruit was then cut laterally and rated 1 to 5 for increasing severity of internal symptoms: 1 for no internal white tissue (IWT) on the inner fruit walls, 2 for a trace of IWT, 3 for $<30 \%$ of the fruit wall area with IWT, 4 for $30 \%$ to $70 \%$ of the fruit wall area with IWT, and 5 for $>70 \%$ of the fruit wall area with IWT. The mathematical relationship between the number of SLWF nymphs and pupae/10 leaflets and subsequent severity of IRR was determined using Pearson correlation coefficients (SAS Institute, 1990).

\section{Results and Discussion}

The relationships between the numbers of sessile nymphs and pupae/10 leaflets and the external and internal IRR ratings generally were positive and significant (Table 1). Highest correlation coefficients for external IRR for both of the two spring seasons tended to occur when fruit ratings were compared to whitefly counts taken 1 week previously, 
Table 1. Pearson correlation coefficients $(P$ value $)$ for the relationship between the numbers of silverleaf whitefly (SLWF) nymphs and pupae and subsequent irregular ripening (IRR) severity.

\begin{tabular}{|c|c|c|c|c|}
\hline $\begin{array}{l}\text { Week after } \\
\text { sampling }^{z}\end{array}$ & Spring 1995 & Fall 1995 & Spring 1996 & Fall 1996 \\
\hline \multicolumn{5}{|c|}{ No. SLWF nymphs and pupae vs. external IRR } \\
\hline \multirow[t]{2}{*}{1} & 0.79 & -0.22 & 0.80 & 0.34 \\
\hline & $(0.0001)$ & $(0.348)$ & $(0.0001)$ & $(0.048)$ \\
\hline \multirow[t]{2}{*}{2} & 0.73 & 0.55 & 0.59 & 0.42 \\
\hline & $(0.002)$ & $(0.0045)$ & $(0.02)$ & $(0.018)$ \\
\hline \multirow[t]{2}{*}{3} & 0.66 & 0.65 & -0.06 & 0.85 \\
\hline & $(0.038)$ & $(0.0005)$ & $(0.878)$ & $(0.001)$ \\
\hline \multicolumn{5}{|c|}{ No. SLWF nymphs vs. internal IRR } \\
\hline \multirow[t]{2}{*}{1} & 0.84 & 0.48 & 0.47 & 0.49 \\
\hline & $(0.0001)$ & $(0.031)$ & $(0.037)$ & $(0.003)$ \\
\hline \multirow[t]{2}{*}{2} & 0.81 & 0.29 & 0.64 & 0.63 \\
\hline & $(0.002)$ & $(0.154)$ & $(0.01)$ & $(0.0002)$ \\
\hline \multirow[t]{2}{*}{3} & 0.68 & 0.41 & 0.06 & 0.59 \\
\hline & $(0.031)$ & $(0.044)$ & $(0.867)$ & $(0.002)$ \\
\hline
\end{tabular}

${ }^{\mathrm{z}}$ Sampling data (no. of SLWF nymphs and pupae) counted on any given week were compared with IRR symptoms observed either 1, 2, or 3 weeks later.

although significant correlations also were obtained when counts were taken two weeks previously (Table 1). In the fall experiments, highest correlations were observed when external IRR fruit ratings were compared to whitefly counts taken three weeks previously, although again significant correlations were observed when counts were taken two weeks previously. With internal IRR ratings, the highest correlation coefficients in both spring seasons were observed when IRR ratings were taken two weeks after nymphal and pupal counts were taken; however, significant correlations were observed when ratings were taken 1 week after whitefly counts (Table 1). Considering both fall experiments, the closest relationships were observed when internal fruit ratings were compared to whitefly counts taken 1 or 3 weeks previously. Thus, the impact of whitefly feeding appeared to be delayed in the fall relative to the spring, particularly for external expression of IRR symptoms. However, in Spring 1995 and Fall 1996, significant correlations were observed for both external and internal IRR symptom expression regardless of whether severity ratings were taken one, two or three weeks after whitefly counts were taken.

The data indicate a significant relationship between the density of SLWF nymphs and pupae and subsequent expression of IRR symptoms. Seasonal effects were suggested be- tween the severity of symptoms and the time delay following infestation until symptoms appeared. These results are not unexpected since temperatures increase as a tomato crop reaches maturity in the spring and decrease as the crop reaches maturity in the fall. As temperature increases to $35^{\circ} \mathrm{C}$, developmental times of SLWF immature lifestages decrease and, presumably, feeding rates increase.

The seasonal influence may present interesting challenges for growers. Spring grown tomatoes would tolerate fewer SLWF immatures, thus requiring quick and effective action on the part of a grower. Fall grown tomatoes could tolerate more whiteflies with more time to take corrective action. In addition, it has been shown previously that more samples are required to precisely estimate lower densities of immature lifestages than higher densities (Schuster, 1998).

\section{Literature Cited}

SAS Institute. 1990. SAS ${ }^{\circledR}$ procedures guide, version 6, 3rd ed., SAS Inst., Cary, N.C.

Schuster, D.J. 1998. Intraplant distribution of immature lifestages of Bemisia argentifolii (Homoptera: Aleyrodidae) on tomato. Environ. Entomol. 27:1-9.

Schuster, D.J., T.F. Mueller, J. Kring, and J.F. Price. 1990. Relationship of the sweetpotato whitefly to a new tomato fruit disorder in Florida. HortScience 25:1618-1620.

Schuster, D.J., J.E. Funderburk, and P.A. Stansly. 1996. IPM in tomatoes, p. 387-411. In: D. Rosen, F.D. Bennett, and J. Capinera (eds.). Pest management in the subtropics integrated pest management-A Florida perspective. Intercept Ltd., Andover, Hants, U.K. 